\title{
Induction of Somatic Embryogenesis from Carrot Seeds by Hypochlorite Treatment
}

\author{
Tomohiro Kiyosue, Hiroshi Kamada and Hiroshi Harada \\ Gene Experiment Center, Institute of Biological Sciences, \\ University of Tsukuba, Ibaraki, 305 Japan
}

(Received May 29, 1989)

(Accepted September 12, 1989)

\begin{abstract}
Somatic embryogenesis was induced from carrot (Daucus carota L. cv. US-Harumakigosun) seeds without any application of plant growth regulators. The seeds were treated with three different kinds of hypochlorite solutions, then cultured on a hormone-free Murashige \& Skoog's agar semisolid medium (0.1 M sucrose, $0.8 \%$ Bacto Agar). After 7 weeks of culture, somatic embryos were formed on the surface of germinated seedlings and/or mericarps of the seeds. When the duration of the treatment with $\mathrm{NaClO}$ or $\mathrm{Ca}(\mathrm{ClO})_{2}$ was longer and the concentration of available chlorite was higher, the frequency of germination decreased while that of somatic embryo formation increased. These results suggest that certain physiological stresses might trigger the induction of somatic embryogenesis in carrot.
\end{abstract}

Since Steward et al. ${ }^{1)}$ and Reinert ${ }^{2)}$ reported in vitro somatic embryogenesis in carrot, this species has been widely used as a model experimental system for physiological and biochemical analyses of somatic embryo formation. ${ }^{3)}$ Generally, carrot embryogenic cells can be induced during the culture of somatic tissues on auxin-containing medium and somatic embryos can be formed by transferring the embryogenic cells to auxin-free medium.4) By using this system, morphological and biochemical events occurring during somatic embryo development from embryogenic cells have been intensively studied and well characterized. ${ }^{3)}$ However, there are only a few reports which have dealt with biochemical events taking place during an initial stage of the induction of plant cell differentiation. One of the reasons for this was due to the fact that auxin treatment has been the only way to induce somatic embryogenesis in carrot. As it is well known that auxin plays an important role in cell elongation, cell division, adventitious root formation, xylogenesis and many other physiological phenomena, ${ }^{5)}$ and these make it difficult to detect only those biochemical changes which are directly related with the induction of embryogenic cells by separating it from other effects. To overcome this difficulty, it is necessary to develop new systems capable of inducing somatic embryogenesis without any application of plant hormones and which allow to compare biochemical changes between non-embryogenic and embryogenic cells.

Recently, it has been noted that some environmental stresses affect various physiological events and alter gene expression in some plant species. $\left.{ }^{6}\right)$ We have found that somatic embryogenesis in carrot could be induced by stress treatments with high concentrations of sucrose, ${ }^{7,8)} \mathrm{NaCl}^{, 9}{ }^{9} \mathrm{NaClO}^{7,10)}$ or heavy metal ions ${ }^{7,11}$ without any application of auxin. A comparable result has been reported by Smith and Krikorian. ${ }^{12)}$ In the present report, we describe details on induction of somatic embryo formation by various treatments with hypochlorite solutions.

\section{Materials and Methods}

Seeds of Daucus carota L. cv. US-Harumakigosun were treated with one of the three different 
hypochlorite solutions : sodium hypochlorite (available chlorite concentration 10\%), potassium hypochlorite (available chlorite concentration 5\%) and calcium hypochlorite solution (filtrate of $6 \%(\mathrm{w} / \mathrm{v}$ ) calcium hypochlorite solution). About 300 seeds were soaked for 15 to $120 \mathrm{~min}$ in each of the hypochlorite solutions mentioned above. In another experiment, seeds were soaked for $45 \mathrm{~min}$ in variously diluted sodium hypochlorite solutions. The treated seeds were rinsed 3 times with sterilized distilled water, and placed in plastic Petri dishes $(\phi 60 \times 15 \mathrm{~mm}$, five seeds per dishes) containing $8 \mathrm{ml}$ of
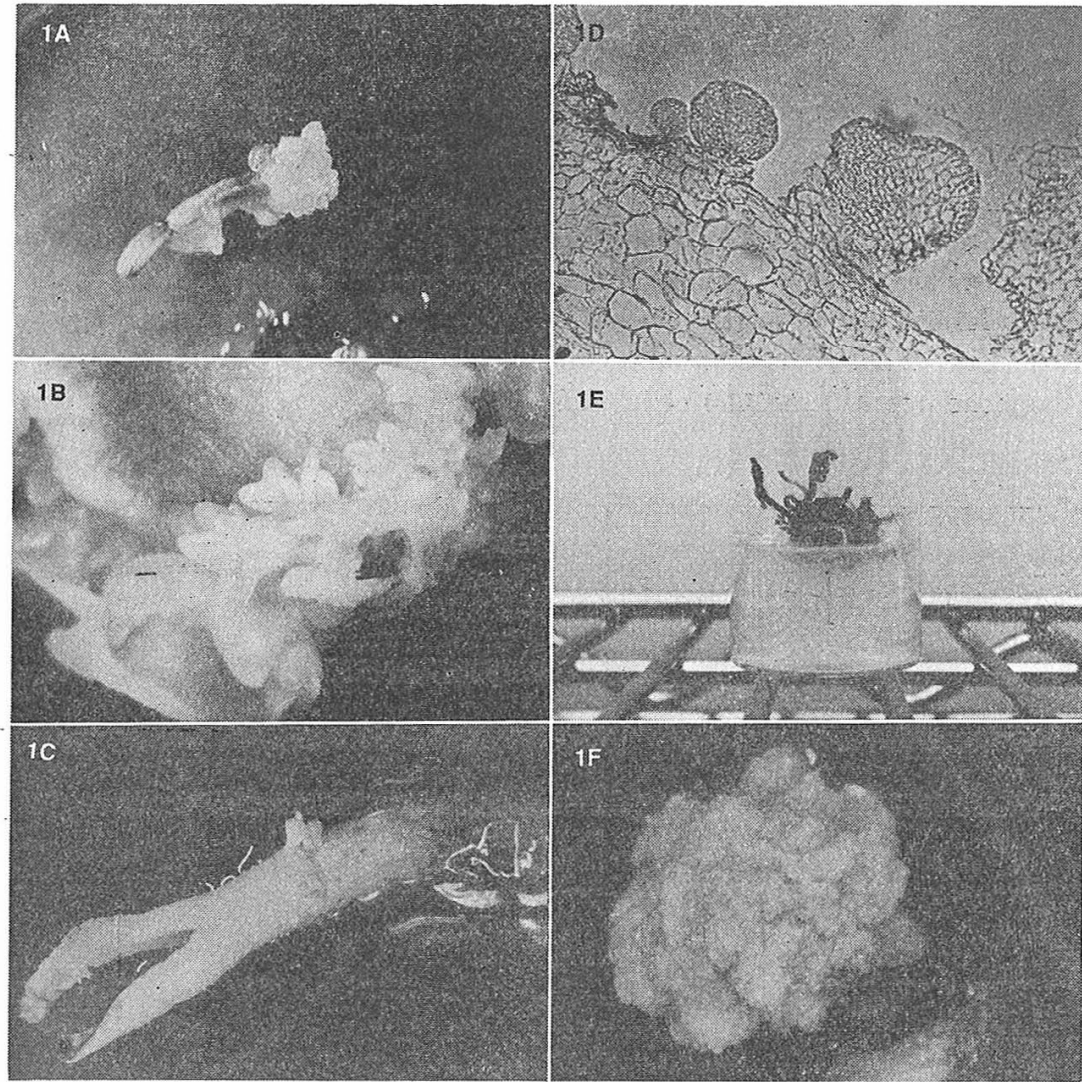

Fig. 1A. Somatic embryos induced by the treatment with $\mathrm{NaClO}$ on the surface of cotyledons and mericarp of carrot. Carrot seed was treated with $\mathrm{NaClO}$ solution (available chlorite concentration of $c a .10 \%$ ) for $60 \mathrm{~min}$ and then cultured on hormone-free MS medium for 7 weeks $(\times 20)$.

Fig. 1B. A magnified photograph of somatic embryos formed directly on the sur. face of the cotyledons which were emerged from a seed. The seed was treated with $\mathrm{NaClO}$ solution for $60 \mathrm{~min}$ and then cultured on hormone-free MS medium for 7 weeks $(\times 60)$.

Fig. 1C. Somatic embryos formed on the surface of a hypocotyl which were induced by the same treatment described in Fig. 1A. $(\times 20)$.

Fig. 1D. A histological section of somatic embryos induced by the $\mathrm{NaClO}$ treatment. Somatic embryos were formed without visible callus formation $(\times 150)$.

Fig. 1E. Young plantlets derived from somatic embryos which were induced by the $\mathrm{NaClO}$ treatment as in Fig. 1B. The photograph was taken 10 weeks after the transfer onto hormone-free -MS medium $(\times 1.2)$.

Fig. 1F. Somatic embryo-like structures from a seed treated with $\mathrm{NaClO}$ solution (available chlorite concentration of $c a .10 \%$ ) for $120 \mathrm{~min}$ and then cultured on hormone-free MS medium for 7 weeks $(\times 40)$. 
hormone-free Murashige and Skoog's agar $(0.8 \%)$ medium (hereafter, referred to as MS medium) with $0.1 \mathrm{~m}$ sucrose. After culturing for 4 days under $16 \mathrm{hr}$ light $/ 8 \mathrm{hr}$ dark $(1,600 \mathrm{lux})$ at $25^{\circ} \mathrm{C}$, randomly selected non-contaminated seeds were transferred to fresh hormone-free MS medium (100 seeds/20 plates) and cultured for 7 weeks under the same conditions. Each experiment was repeaded at least 3 times.

For histological observations, cultured tissues were embedded in O. C. T. compound (Miles Scientific Lab., USA), frozen, and then cut into $20 \mu \mathrm{m}$ sections by using COLDTOME (SAKURA Seiki Co., Japan, MODEL CM-41).

\section{Results and Discussion}

When carrot seeds were treated with $\mathrm{NaClO}$ solution at high concentration (available chlorite concentration 10\%) for $60 \mathrm{~min}$ and planted on hormone-free MS medium, some of them germinated and developed to normal seedlings but others did not germinate or developed to malformed seedlings within one week. Somatic embryos differentiated on the surface of such malformed seedlings and/or mericarps of the seeds after more than 4 weeks of the successive culture on MS medium (Fig. 1 A-C). Somatic embryos were also formed on the surface of cotyledons and hypocotyls of the seedlings without visible callus formation (Fig. 1D). These somatic embryos developed into young plantlets by subsequent transfer onto hormone-free MS medium (Fig. 1 E).
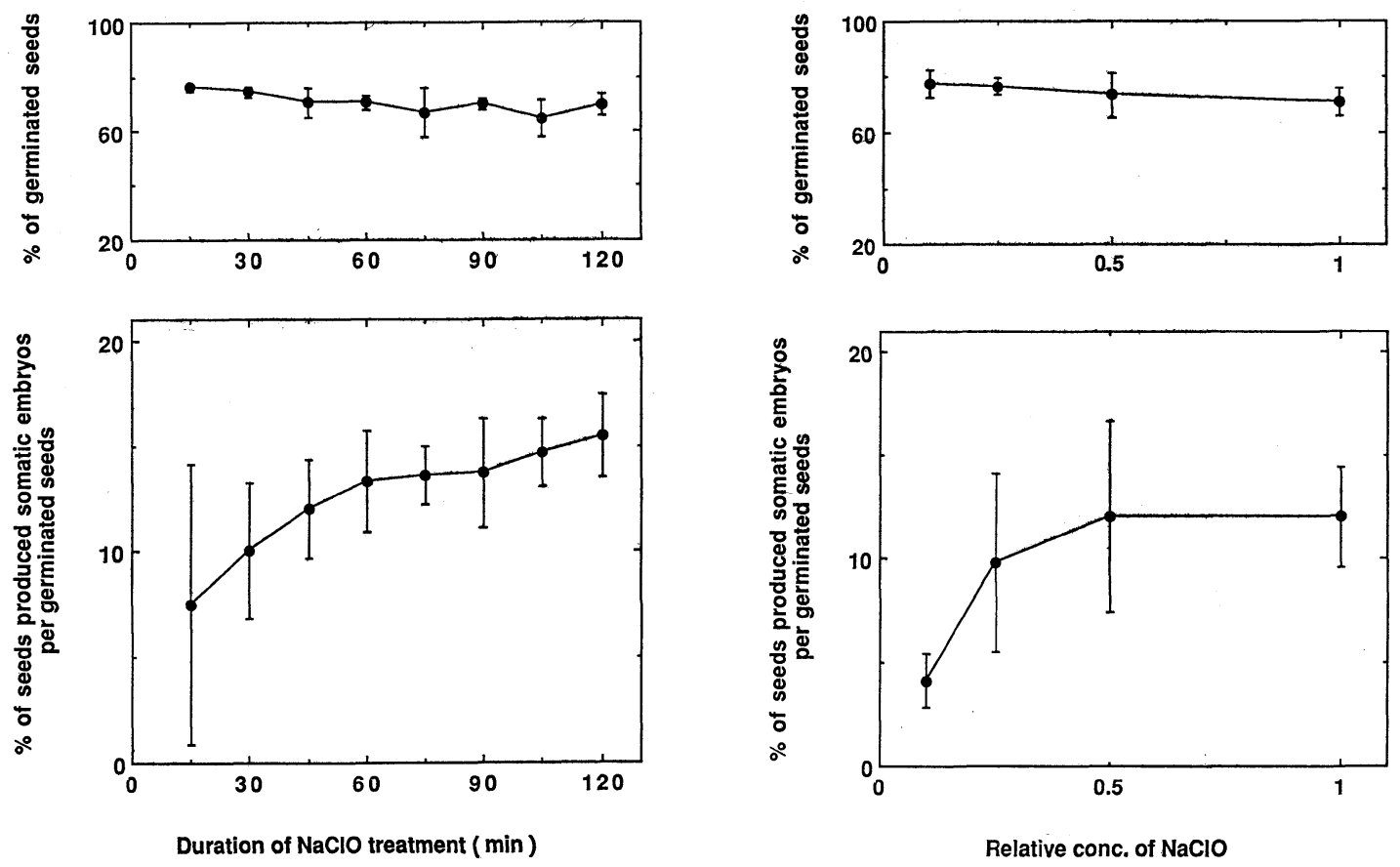

Fig. 2. Effects of the duration of $\mathrm{NaClO}$ treatment on seed germination and somatic embryo formation in carrot. Seeds were treated with $\mathrm{NaClO}$ solution (available chlorite $\mathrm{ca} .10 \%$ ) for 15 to 120 $\mathrm{min}$ and then planted on hormone-free MS medium. Both frequencies were determined after 7 weeks of the culture. Error bars represent standard error of the mean.

Fig. 3. Effects of $\mathrm{NaClO}$ concentrations on seed germination and somatic embryo formation. Seeds were treated with commercially available $\mathrm{NaClO}$ solution (available chlorite ca. 1 to 10\%) for 45 min and then planted on hormone-free MS medium. Each value was determined as described in Fig. 2. Error bars represent standard error of the mean. 
Effect of $\mathrm{NaClO}(10 \%)$ treatments with various durations showed lower germination rate with longer treatment duration (Fig. 2). On the other hand, the frequency of somatic embryo formation increased with the prolonged duration of treatment. Average values of the frequency were $7.5 \%$ and $15.3 \%$ by the treatment for $15 \mathrm{~min}$ and $120 \mathrm{~min}$, respectively. In the case of $60 \mathrm{~min}$ treatment, somatic embryos were formed on cotyledons, hypocotyls and true leaves of young seedlings with different frequencies of $64 \%, 15 \%$ and $2 \%$, respectively. These somatic embryos could develop into young plantlets (Fig. 1 E). Whereas, multiple globular embryo-like structures were formed at the emerging sites of zygotic embryos. However, most of these structures grew continuously maintaining the original structures and did not develop to be whole plantlets during subsequent 6-week culture and even after a transfer onto new medium (Fig. 1 F). Formation of these structures occurred scarcely by a shorter treatment but observed frequently by a longer treatment. Similar phenomena were noted in the cases of $\mathrm{NaClO}$ treatment for $45 \mathrm{~min}$ with high concentrations and of the treatments with other hypochlorites.

In another experiment, we examined the effects of $\mathrm{NaClO}$ concentrations keeping the duration of treatment for $45 \mathrm{~min}$ (Fig. 3). With increasing concentrations of $\mathrm{NaClO}$, the frequency of somatic embryo formation increased and germination frequency decreased gradually. In order to clarify whether hypochlorite concentrations or metal elements were essential to induce somatic embryogenesis, we also examined effects of $\mathrm{KClO}$ and $\mathrm{Ca}(\mathrm{ClO})_{2}$ solutions. Somatic embryos were formed by the treatment
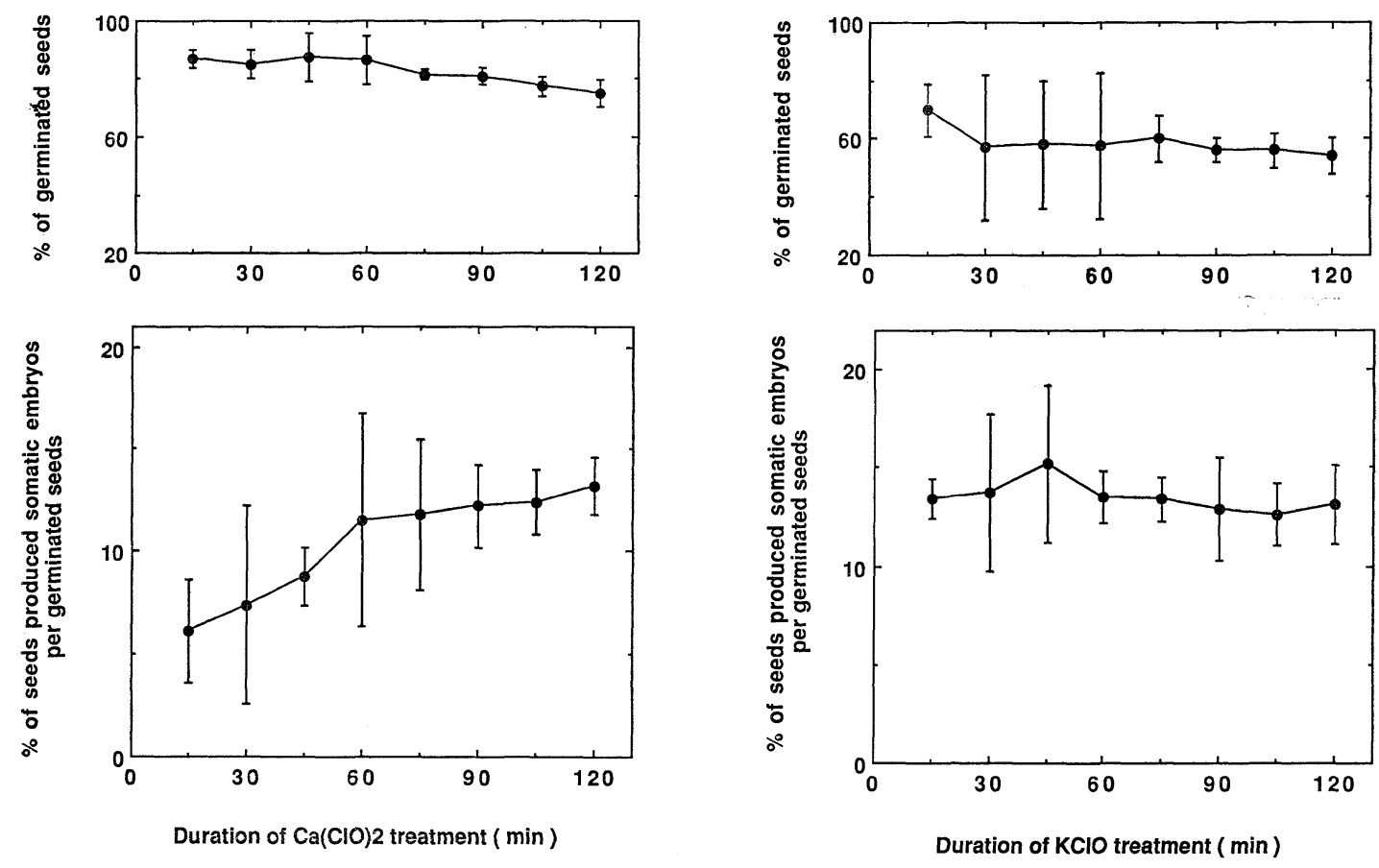

Fig. 4. Effects of the duration of $\mathrm{Ca}(\mathrm{ClO})_{2}$ treatment on seed germination and somatic embryo formation. Seeds were treated with the filtrate of $6 \%(\mathrm{w} / \mathrm{v})$ calcium hypochlorite solution for 15 to $120 \mathrm{~min}$ and then planted on hormone-free MS medium. Each value was determined as described in Fig. 2. Error bars represent standard error of the mean.

Fig. 5. Effects of the duration of $\mathrm{KClO}$ treatment on seed germination and somatic embryo formation. Seeds were treated with $\mathrm{KClO}$ solution (available chlorite ca. 5\%) for 15 to $120 \mathrm{~min}$ and then planted on hormone-free MS medium. Each value was determined as described in Fig. 2. Error bars represent standard error of the mean. 
with $\mathrm{Ca}(\mathrm{ClO})_{2}$ solution and the frequency increased with longer treatment (Fig. 4). In the case of $\mathrm{KClO}$ treatment (Fig. 5), germination frequency and the frequency of somatic embryo formation were slightly higher in the short treatments of 15 and $45 \mathrm{~min}$, respectively, and remained at constant values in longer treatments (60 to $120 \mathrm{~min}$ ). Although the reason why the ability to induce somatic embryos is somewhat different among $\mathrm{KClO}, \mathrm{NaClO}$ and $\mathrm{Ca}(\mathrm{ClO})_{2}$ remains to be unknown, metal elements or some contaminating substances in commercially available hypochlorite solutions may give certain toxic effects to somatic tissues.

Somatic embryogenesis in several plant species can be readily induced by transferring explants from auxin-containing medium to auxin-free medium. ${ }^{1-4,13 ; 14)}$ In the case of carrot and also in many other plant species, auxin concentration added to the culture medium is generally extremely high in comparison with endogenous level of auxin, and 2,4-D is more effective than natural auxins, such as. IAA. Thus, it is likely that exogenously applied auxin to induce embryogenic cells acts, at least partly, as a stress. Indeed, it was reported that high concentration of exogenously applied auxin induced expression of several genes which were preferentially expressed by heat shock or salt or heavy metal stress. ${ }^{15)}$ Furthermore, somatic embryogenesis in carrot was also observed when apical tips of young seedlings were cultured on hormone-free MS medium after a treatment with a high concentration of sucrose, mannitol, ${ }^{7,8)} \mathrm{NaCl}^{9}$ or heavy metal salts ${ }^{7,11}$ such as $\mathrm{CdCl}_{2}, \mathrm{FeCl}_{2}, \mathrm{CoCl}_{2}, \mathrm{NiCl}_{2}, \mathrm{CuCl}_{2}$ and $\mathrm{ZnCl}_{2}$ under auxin-free conditions. In this report, we demonstrated that somatic embryogenesis from the carrot seed was stimulated by hypochlorite treatments. There are at least two possible explanations for this result : 1) the hypochlorite treatments make some somatic cells competent to form somatic embryos and the process of somatic embryogenesis can proceed by subsequently culturing them on appropriate medium, or 2) the axenic culture itself on MS medium makes certain somatic cells competent and the treatment with hypochlorite solution enhances its effects. However, by considering the facts described above, it is possible that the stresses caused by the chemicals employed trigger the induction of somatic embryo. genesis in carrot. 1

So far, we are not able to induce somatic embryogenesis by the treatment with hypochlorite solution in other plant materials than carröt seeds. It is known that somatic embryogenesis in Brassica campestris $^{16)}$ can be induced directly from the surface of immature zygotic embryos but not from mature tissues such as leaves. This fact may indicate that zygotic embryos easier become competent to form somatic embryos than other somatic tissues.

Our demonstration of the induction of somatic embryogenesis by culturing carrot seeds on hormonefree MS medium with the treatment with hypochlorite solution will provide us a new possibility for biochemical studies on somatic embryogenesis.

Authors thank Dr. V.S. Jaiswal for his linguistic suggestings.

\section{References}

1) Steward, F. C., M. Mapes., K. Mears, 1958. Am. J. Bot., 45 : 707-708.

2) Reinert, J. 1958. Ber. Dtsch. Bot. Ges., 71: 15.

3) Nomura, K., A. Komamine, 1986. Oxford Surveys Plant Mol. Cell Biol., 3: 456-466.

4) Fujimura, T., A. Komamine, 1979. Plant Physiol., 64: 162-164.

5) Sharp, W. R., P. O. Larsen, E.F. Paddock, V. Raghavan, 1979. Plant Cell and Tissue Culture, p. 221-262, Ohio State University Press, Columbus.

6) Sachs, M. M., T. H. D. Ho, 1986. Ann. Rev. Plant Physiol., 37 : 363-376.

7) Kamada, H., T. Kiyosue, H. Harada, 1988. Abstracts of 39th Annual Meeting of the Tissue Culture Association, p. 71 A No. 237.

8) Kamada, H., K. Ishikawa, H. Saga, H. Harada, 1988. Plant Cell Rep. (submitted).

9) Kiyosue, T., H. Kamada, H. Harada, 1989. Plant Tissue Cult. Lett., 6: 162-164.

10) Kiyosue, T., H. Kamada, H. Harada, 1987. Abstracts of Japanese = Association for Plant Tissue Culture 10th Meeting, p. 164.

11) Kamada, H., K. Kobayashi, T. Kiyosue, H. Harada, 1989. In Vitro Cellular and Developmental 
Biol. (in press).

12) Smith, D. L., A. D. Krikorian, 1988. Plant Sci., 58 : 103-110.

13) Lu, C., V. Vasil, I. K. Vasil, 1983. Theor. Appl. Genet., 66 : 285-289.

14) Wernicke, W., R. Bretell, 1980. Nature (Lond.), 287 : 138-139.

15) Czarnecka, E., L. Edelman, F. Schoffl, J.L. Key, 1984. Plant Mol. B1ol., 3: 45-58.

16) Maheswaran, G., E. G. Williams, 1986. J. Plant Physiol., 124 : 455.

\title{
《和文要約》
}

\section{次亜塩素酸によるニンジン種子からの不定肧誘導}

\author{
清末知宏，鎌田 博，原田 宏
}

\section{筑波大学遺伝子実験センター}

植物ホルモンを使用しないでニンジンの種子から不定肧形成を行わせることに成功した. ニンジン種 子を 3 種類の次髙塩素酸溶液に浸漬した後, 植物ホルモンを含まない Murashige \& Skoog 固形培地 （ショ糖 $0.1 \mathrm{M}$, 寒天 $0.8 \%$ ）上で培養を行ったところ, 不定胚形成が認められた. 次亜塩素酸処理時間 や処理濃度が高まるにつれて種子の発芽率は減少する傾向を示したが，逆に不定胚形成頻度は上昇する 傾向を示した. これらの結果は, ストレスがニンジン不定胚形成能誘導に関与しているという可能性を 示唆する新たな証拠であると考えられた. 